\title{
The Havana Charter: when state and market shake hands Jean-Christophe Graz
}

in Rainer Kattel, Jayati Ghosh \& Erik Reinert (Eds), Handbook of Alternative Theories of Economic Development, Aldershot : E. Elgar, 2016, pp. 281-290.

| < a $>$ INTRODUCTION

The Havana Charter is the Final Act of the United Nations Conference on Trade and Employment held in the Cuban capital in 1947-1948. It set up the status of the International Trade Organization (ITO), the third international economic organization planned for the post-World War II era alongside the International Monetary Fund (IMF) and the World Bank. Most scholars have neglected the importance of the Havana Charter as a milestone of many contemporary issues, such as the general framework requested for multilateral trade negotiations, their relations with full employment policy, commodity agreements, provisions intended to curb cartels and anti-competitive policies, as well as many early concerns still on the agenda of development policies. ${ }^{1}$ The main reason for this lies in the stillborn nature of the agreement. In 1950, the United States (US) Congress declined to ratify the treaty, which in turn induced all the other 53 signatory states to abandon the attempt to establish the organization. What remained were the General Agreement on Tariffs and Trade (GATT), which was very similar to one chapter out of nine included in the Havana Charter, and some provisions included in other institutional arenas.

How does the study of the Havana Charter contribute to our understanding of the global economic order in which situating alternative development policies? This historical inquiry helps us to forge a critical assessment on current potentials for change in various ways. First, regarding the international trading system, it sheds light on challenges raised by non-tariff measures in the current context of 'deep integration'. With tariffs reduced virtually to non-existence, and more discipline imposed on important non-tariff measures such as quantitative restrictions, trade negotiations now revolve mostly around those aspects of domestic policies that are deemed to have an impact on trade. One only has to think of the heated debates surrounding the Transatlantic Trade and Investment Partnership and the Trans-Pacific Partnership negotiated between the United States and, respectively, the European Union and 11 countries around the Asia Pacific region. The issue has little to do with protectionism, even if it could be captured by protectionist forces, for the distinction between trade policy per se and state-market relations in general is considered to have become increasingly blurred. As Pascal Lamy, former Director General of the World Trade Organization (WTO), put it in the foreword of the 2012 World Trade Report focused on non-tariff measures: 'Regulatory interventions addressing market failures and international spillovers, with inevitable consequences for trade flows and investment, are here to stay' (World Trade Organization 2012). A careful study of the Havana Charter provides evidence that the comprehensive scope of non-tariff measures was already a key issue of the post-war international trading system. Even if the neoliberal drive of globalization has since had a deep impact on the WTO agenda, similar patterns of disputable issues remain.

Second, from a broader political economy perspective, many lessons can be drawn from the way the Havana Charter attempted to establish a mutually compatible set of policies blending free-trade objectives with recognition of state intervention in the domestic sphere and sectoral aspects of international trade. Commitments to restore a liberal economy after the war came up against a new form of state legitimacy that relied heavily on various instruments of the welfare state, Keynesian macroeconomic policy and development planning. This peculiar juncture between market freedom and the protection of international exchanges reflects in many ways the guiding principle of state intervention in classical mercantilism. In contrast to conventional accounts, a key criterion in the mercantilist understanding of the balance between freedom and protection of trade was the value in use, and more specifically its productive potential (Reinert 2008; Perrotta 1991). The Havana Charter helps us to translate this understanding into the contemporary debate. This chapter argues that the tension that exists when state practices are put to the test by the transnational drive of capitalism can be conceptualized as a form of transnational mercantilism (Graz 2004). In the post-World War II era, the external impact of these measures was expected to be contentious enough to trigger a bold attempt to normalize a wide range of state-society relations, considered for their impact on trade. The project did not survive US trade politics because it faced up to the impossibility of reaching a broad international understanding on the proper balance between market rules and state intervention.

The chapter first recasts the history of the ITO negotiations and their demise once the US Congress refused to ratify the agreement. It then pays particular attention to the principles and provisions of the Havana

\footnotetext{
${ }^{1}$ For a detailed study on the International Trade Organization project by the author of this chapter, see Graz (1999). The ITO forms a part of the classical study of Richard Gardner (1969); see also, more recently, Zeiler (1999) and Toye (2003).
} 
Charter with regard to development issues. The following section brings up the significance of the stillborn ITO from a critical international political economy perspective. The conclusion summarizes the lessons to draw from a contemporary point of view.

\section{$<\mathrm{a}>$ A SHORT HISTORY OF THE ITO PROJECT}

The ITO is the third institution that should have been set up along with the IMF and the World Bank in the postwar era to implement the articulation between international security and economic and social welfare laid down in the United Nations Charter. Its institutional origins go back to the early post-war international economic and political commitments undertaken by the Allies in the Atlantic Charter and the American Lend-Lease policy. Article 7 of this agreement enjoined the Allies to open negotiations on a number of key normative issues for the post-war era as a counterpart to American military and financial support during the war. This article may be considered to be the first step towards reconciling the historic antagonisms between an open international economy and socio-economic functions of the states directed to welfare, full employment and development objectives. From the outset, post-war planners from both sides of the Atlantic were deeply concerned by a comprehensive conception of international trade regulation, which blended free trade objectives with a recognition of important state interventions in various aspects of the economic sphere. Among them were some of the most distinguished scholars who wrote about the challenge in the late 1930s as well as after the beginning of the war (Toye and Toye 2004). One of the first documents on economic war aims produced by the group of experts established by the Council on Foreign Relations even before the American entry into World War II contains, for instance, the following comment:

<quotation>It is doubtful if the idea of free trade now has very much appeal save to a small group of business men and economists. Nor is it likely that anything approaching free trade will be achieved for a long time to come. Rather we should stress the value to all concerned of a great interchange of goods, to be brought about in part by a removal of trade barriers and in part by positive measures of government policy. ${ }^{2}<$ quotation $>$

Though different in its content, the first exploratory draft of what was to become the Havana Charter reflects similar concerns. The 'Commercial Union' scheme was originally drafted by James Meade, then a member of the Economic Section linked to the British Cabinet Offices. It was subsequently circulated among British and Dominions officials between autumn 1942 and spring 1943. One of them produced a striking criticism on the issues at stake:

$<$ quotation $>$ There is, I think, a fairly widespread illusion that those who are in favour of the Commercial Union scheme are supporting a policy of 'laissez-faire'. The choice is not in fact between 'laissez-faire' and planning but between international planning which, if successful, will leave room for a certain amount of internal 'laissez-faire' and the advanced degree of internal planning and control necessary to deal with a situation created by international 'laissez-faire'. The latter course must in my view eventually mean state socialism or something very like it. ${ }^{3}<$ quotation $>$

These statements give evidence of a deep concern about a mutually compatible set of both liberal and interventionist policies as the sole alternative to both fascism and communism. They explain the comprehensive agenda laid down for the first Anglo-American talks held in autumn 1943 at Washington on the trade-related questions raised by the Article 7 commitments. These discussions hinged not only on tariff-reduction formulas, trade preferences and quantitative restrictions, but also on their relation with subsidies, intergovernmental commodity agreements, international cartels, state trading and, finally, on the policy autonomy required for a proper implementation of macroeconomic instruments directed to employment and social objectives. Moreover, any commercial commitment depended on the conclusion of a satisfactory agreement on monetary and financial issues. Priority was given then to negotiations that eventually led to the Bretton Woods Agreements.

Contrary to the usual accounts privileging the hegemonic leadership taken by the United States, the ITO project was an outcome of close plurilateral negotiations even before formal international negotiations took place between 1946 and 1948. The harsh compromises sought in the negotiations resulted from strong supporters as well as arch-opponents at each national level. For instance, whereas in the United States the supporters were coalescing around capital-intensive, globally competitive industries and their financial allies, in the United Kingdom, the cluster came more from pragmatic considerations with regard to the huge balance of payment disequilibrium foreseen in the post-war era. The opponents included, on both sides of the Atlantic, radical labour, farm interests, a wide range of labour-intensive and poorly competitive small and medium-range

\footnotetext{
2 'Economic War Aims: General Considerations, the Position as of April 1, 1941', memorandum E-B32, 17 April 1941, Council on Foreign Relations, Economic and Financial Group, 14.

${ }^{3}$ W.L. Gorell Barnes to Lord President, 18 March 1943, Public Record Office, Kew (UK), CAB 123/221.
} 
industries, financial interests linked to the Sterling Area and the New York bankers gradually opposed to the Bretton Woods Agreements.

It was not until after the Anglo-American Loan Agreement of December 1945 that the American and British governments committed themselves publicly to establishing an International Trade Organization as a trade-off to financial assistance. Two more preparatory sessions were held in London and Geneva in 1946 and 1947 before the opening of the United Nations Conference on Trade and Employment in Havana from November 1947 to March 1948. These negotiations were not confined to the most powerful trading powers of the post-war era. More than 30 countries joined the negotiations at this later stage, most of them from Latin America under the leadership of Argentina at its peak of Peronist economic nationalism and independent industrialization. It is in this context that the so-called 'underdeveloped' countries launched a wholesale attack against the provisions drafted during the previous preparatory conferences. They saw them as too one-sided in favour of rich countries, without consideration for the emergent issues of economic development. As Clair Wilcox, head of the US delegation, later recollected, 'The most violent controversies at the conference and the most protracted ones were those evoked by issues raised in the name of economic development' (Wilcox 1949, 46).

This took place at a time when, in Washington, State Department free traders had gained influence after the death of President Roosevelt in April 1945. The Truman administration marginalized left-wing New Dealers who tried to put on an equal footing trade liberalizing provisions and guarantees directed at full employment and economic planning. The British were ready to go along with the American line to restore a liberal international economy, but would not abandon Imperial Preferences altogether (the system of discriminatory tariffs negotiated during the Ottawa Conference of 1932 in order to reinforce commercial and financial solidarity within the Empire). Moreover, the Labour Party, which won a historic victory at the general elections held after the end of the war, was keen on giving as much weight to welfare state commitments as to external adjustment constraints. Therefore, British delegates keenly defended all provisions able to render both objectives compatible. Most European delegations shared that perspective. Yet, it was clearly the Australians and New Zealanders who pushed further innovative thinking by making a parallel between full employment and economic development objectives. They also maintained that restraints to trade for implementing such a bold programme should in some circumstances be discriminatory. In this respect, the Southern Dominions often upheld 'underdeveloped' countries' demands. Trading powers such as the United States or the United Kingdom were ready to take into consideration special provisions for development purposes. But they deeply underestimated the weight of those demands and the extent of concessions necessary to reach compromises on each topic raised by this agenda. As Raul Prebisch, founding Secretary-General of the United Nations Conference on Trade and Development (UNCTAD), later emphasized in its report to its first conference in 1964, 'the absolute necessity of industrialization for the peripheral countries had not been recognized or realized' (quoted in Toye and Toye 2004, 42). Yet, as will be seen later, such demands already went a step ahead of what free trade advocates on Capitol Hill would ever be ready to accept. This can be understood as a direct outcome of the 'procedural multilateralism' (Toye and Toye 2004, 18) that the United States privileged to devise the purposes and forms of post-war organizations by international negotiation between prospective members rather than by mere power and supremacy. This reversal of political fortune reflects an American hegemonic movement less centrifugal - and thus more polycentric - than usually assumed. In his recent study of the forgotten development foundations of Bretton Woods, Helleiner also emphasizes how in this context the early United States support for reconciling liberal economic order with the development aspirations of emerging Southern powers unravelled (Helleiner 2014, 258ff).

When in March 1948 the time finally arrived for signing the Havana Charter, many aspects of the initial momentum had already vanished. The concentration of the Truman administration on the intensification of the Cold War had significant implications for the fate of the ITO. However, a failure of the Havana Conference would be seen as a failure in the leadership that the United States claimed for the 'free world'. Facing the bulk of amendments forwarded at the negotiation table, Clair Wilcox, the chief of the US delegation at Havana, thought of adjourning the conference as the only remaining answer to the challenge. But Washington briefed him that 'a weak Charter was better than none'. ${ }^{4}$ In the context of the beginning of the Marshall Plan and the early North Atlantic Treaty Organization (NATO) planning, the Charter was not submitted to the United States Congress before spring 1949, and another year passed before hearings took place. The bill was never put to the floor of the House. Eventually, in December 1950, one could find, in the middle of a lengthy press release from the State Department about the GATT conference under way at Torquay in the UK, that the President agreed not to resubmit the ITO Charter to Congress. Because the Charter was never ratified by the US Congress, all the other signatory states abandoned the attempt to establish the organization.

\footnotetext{
4 'If we get a Charter in March' and 'Possible adjournment of Havana Conference', Wilcox to Clayton, 29 December 1947; Brown to Clayton, 30 December 1947; Lovett to Wilcox, 3 January 1948; Brown to Wilcox, 5 January 1948; National Archives and Records Administration of the United States, Record Group 43 (Records of international conferences, commission and expositions), LF 47D-284 (international trade files), box 144.
} 
The ITO's comprehensive agenda did not survive US trade politics. It faced the impossibility of reaching a broad international understanding on the proper balance between market rules and state intervention. The attempt to create a long-term comprehensive international organization gave way to ad hoc initiatives. Programmes such as the Marshall Plan and its various institutional extensions such as the Organisation for European Economic Co-operation (the forerunner of the OECD) offered an effective, though much more liberal, alternative to the Havana Charter. As far as the GATT is concerned, up to the 1980s it was devoted mainly to tariff reductions; GATT remained vague on non-tariff measures, and early attempts to tackle this agenda in the 1960s and 1970s yielded meagre results. It would take another decade before the $1961 \mathrm{UN}$-sponsored development decade would address development issues negotiated at Havana. Economic development and regulation of trade in commodities became salient issues only in the 1960s after the creation of UNCTAD and would wait further for the oil crisis and the claims to a new international economic order to come to the forefront of the international agenda. Regarding full employment and other welfare provisions of the Charter, policies were incrementally implemented at the national level. It transformed national economic policy of state practice throughout the industrial world. But it remained mainly an issue bounded by the territorial state.

\section{$<\mathrm{a}>$ HOW DID THE HAVANA CHARTER CONSIDER DEVELOPMENT ISSUES?}

The Havana Charter was the first ever attempt to reach a comprehensive intergovernmental agreement for underpinning a compatible set of precise rules to synthesize international liberalism with a high degree of policy autonomy at the domestic level. The aim was to promote both social justice and economic growth on a multilateral basis by recognizing conflicting needs amongst countries and social classes. It is in this respect that the ITO tried to strike a balance between freer trade, full employment and development needs. Among the delegations that took part in the negotiations, few could disagree with these broad goals, but many disagreed on the proper balance to strike on this comprehensive agenda.

Unsurprisingly, the final text of the Havana Charter was thus a patchwork of last-minute compromises on most issues related to this comprehensive agenda. Within the extraordinary complexity of the agreement, the acceptance of divergent needs of member states according to economic development objectives and planning policies became a critical issue, closely related to the extent to which discriminatory barriers to trade and the provisions for establishing intergovernmental agreements in primary commodities, and avoiding restrictive business practices from cartels, are accepted. While the balance between free-trade objectives and restrictions to trade for full-employment considerations was at the core of early post-war planning, the Havana conference set the pace for a broader international understanding on the proper balance between market rules and state intervention by including core issues of economic development. Chapter III of the Charter thus designed special provisions 'particularly for those countries which [were] in the early stage of industrial development'. Developing countries were successful in giving to it a very broad reading, including tariff preferences, quantitative restrictions and limitations of investors' rights. Let us have a closer look at each of those provisions pointing to forgotten routes for alternative economic development.

A key objective of American post-war planning regarding the international economic order was the abolition of trade preferences established by colonial powers such as Britain and France. This so-called 'open door' policy dates back to the late nineteenth century with the rise of the United States as a global economic power seeking access to world markets. The two key principles for non-discrimination in trade policy still at the core of the current trading system also lie at the core of the Havana Charter. Article 16 lays down an unconditional 'most-favoured nation' clause, which calls for members of a commercial treaty to grant one another the most favourable treatment which they grant to any other trading partner. This obligation is closely related to Article 18 on 'national treatment', securing non-discriminatory treatment of imported goods once they have cleared customs so that foreign goods can be treated equally to domestic goods in the national economy. However, it is remarkable to note that most exceptions provided by the Havana Charter to those two nondiscrimination principles were instigated on development grounds at a time when international development policy had hardly reached the official circles of the United Nations. Besides provisions for agreed customs unions or free trade areas taking into account early plans for European integration (Article 44), preferential tariff agreements were also explicitly imagined for development purposes (Article 15). Such provisions sheltering a market for particular industries or branches of agriculture parallel early plans for regional market integration and coordination related to import-substituting industrialization strategies. Finally, a third exception to the principle of non-discrimination concerned the use of quantitative restrictions in cases of serious balance-of-payments problems (Article 23). This clause was primarily related to the extreme situation of Britain, as well as European and other sterling area countries, in lack of dollars to import goods from the United States, which at that time produced half of the world output and where virtually all monetary reserves had been accumulated. Yet, the principle also anticipated ways for developing countries to pin down how to avoid chronic shortages of hard currencies turning into deep crises of balance of payments and sovereign debt defaults. 
In addition to exceptions to the principle of non-discrimination, the use of quantitative restrictions along with tariffs for protecting new industries was a cornerstone of the principles of economic development embodied in the Charter. The American delegation was strongly opposed to quotas identified as a betrayal to the price mechanisms at the basis of a market economy. On the contrary, delegates from developing countries, supported by those from Australia, continuously highlighted that competitive price mechanisms could not be applied in a context of infant industries. At the end of strenuous negotiations, they were eventually successful in devising a so-called automatic approval (Article 13.7) whenever quotas would be applied to protect industries established during the war in substitution to the disruptions of the conflict (the so-called 'war babies' developed by many Latin American countries), or to support industries processing primary commodities and facing a sharp fall in exports resulting from new or increased trade restrictions imposed abroad. The Charter also included provisions for quotas in case the organization to be established considered them 'necessary ... to promote the establishment or the development of a particular industry for the processing of an indigenous primary commodity' (Article 13.7.a.iii), as well as for any measure considered unlikely to be more restrictive of trade than permissible measures. Although entailing considerable margins for disputable interpretations, all those provisions unmistakably broke new ground for the principle of special and differentiated treatment for developing countries embodied in the GATT and, much later, in the WTO. Their extensiveness has no common measures with the broken promises of the Doha Development Agenda launched in 2001.

Together with the use of quotas, the investment provisions of the Charter became the most controversial issues under negotiation. In line with the principle of a mutually compatible set of both liberal and interventionist policies, Article 12 of the Charter was designed to recognize the role of private and public investment in promoting economic development, and to frame a favourable environment for the flows in capital and, at the same time, offering guarantees to borrowing countries against adverse interference in domestic affairs with rights to set conditions affecting existing and future investments on their own terms. The Charter implicitly recognized the right of expropriation of foreign investment by host countries with due compensation and entitled them to impose specific requirements on any foreign investment. Host countries could also take 'any appropriate safeguards' to prevent foreign direct investment from interfering in their domestic policy and could decide whether to approve or to deny access to future investment. While net capital flows to developing countries were mostly private, confined to raw materials and at levels far from those reached decades later in the context of globalization, those provisions anticipated in many ways the principle of 'full permanent sovereignty of every State over its natural resources and all economic activities' embodied some 25 years later in the Declaration on the Establishment of a New International Economic Order adopted by the Sixth Special Session of the UN General Assembly in 1974.

Finally, new ground was broken with respect to the special difficulties that affected the production and trade in primary commodities such as mining and agricultural products. Both developing and industrialized countries agreed to establish procedures for temporary intergovernmental commodity agreements based on a regulation of price and production (Chapter 6). Buffer stocks were excluded, though, since the US delegation continuously opposed them despite the strong case made in their support within the Department of Agriculture. The aim was to bring price and revenue stability for primary producers and consumers. At the time, this agreement was path-breaking. The collapse of primary products prices had severely affected all countries in the interwar period, and the Charter attempted to provide a practical alternative that would permit and encourage marketing boards and other market-limiting institutions. In addition, special provisions were designed to guarantee effective support to the agricultural sector through subsidies and quantitative restrictions (Articles 20, $22,27)$.

\section{$<\mathrm{a}>$ THE SIGNIFICANCE OF THE HAVANA CHARTER}

It is hard to imagine within the present context that one of the most important chapters in the management of international trade relations put on an equal footing the freeing of trade with restrictions required for full employment and economic planning. Yet these apparently contradictory provisions were the key elements of the negotiating process that led to the Havana Charter. Beyond Anglo-American dissensions on their respective ability to control the international economic order at the end of the hostilities, post-war planners in London, Washington, Paris, New Delhi and Canberra all shared a conception of a trading order which should strike a balance between free-trade objectives and substantial state interventions in socio-economic policy and several sectoral aspects of international trade. This conception marks a profound shift as compared to pre-World War II arrangements that only targeted the freeing of goods and capital movement within a Gold Standard environment: an ideal of classical liberalism which meant more often than not unemployment and downward pressure on wages. The ITO mandate was totally different.

In the same way as classical mercantilism fostered the development of the modern state by reinforcing its selective and differentiated role as incentives in production, finance and trade, the Havana Charter supported a new form of state legitimacy relying on key interventions in various aspects of the economic sphere. At stake 
was the external impact of these measures when, at the same time, states committed themselves to restoring a liberal economy at the international level. This can be captured by the apparently contradictory concept of transnational mercantilism. If states hold themselves accountable to one another in such circumstances, it is because the comprehensive understanding of the proper balance between market rules and state intervention points to the very heart of their legitimacy.

To see mercantilism as transnational is not as absurd as it might initially seem. Mercantilism was not simply state-centred, inward-looking or power-seeking (Reinert 2008; Perrotta 1991; Hont 2005). The transnational dimension entails the idea of a dynamics that goes both through and beyond the territoriality of state practice. The question, then, is how the fine-tuning of state practices is put to the test by the forces involved in a world-scale drive of capitalism. Recent and prominent scholarship on economic development in the post-Washington Consensus era echoes such concerns by pleading for an end to grand and misleading generalizations regarding the benefits of market or state planning, and a focus instead on micro impacts of development policies through detailed analysis and field research (Banerjee and Duflo 2011). While the burden of proof remains closer to market rules than state intervention in this perspective, the idea that economic policies can be valued on a pragmatic political basis instead of opposite rigid principles seems to have gained credit for providing space to reformist ideas in economic development thinking, let alone for more radical alternative routes in development policies.

Coming back to the World Trade Report 2012 sketching some of the main challenges in adapting the WTO to a world 'beyond tariffs', it is also worth noting that the WTO analysis has now moved some distance from the market fundamentalism that marked its creation. For the WTO, non-tariff measures do not necessarily serve protectionist purposes and can just as well fulfil legitimate public-policy goals, in particular in the domain of services where regulation and standards are crucial for quality and security purposes. Without explicitly making the comparison with the Havana Charter, the report concludes, however, on a similar note when it highlights that future challenges include 'finding the right mix between international commitments and domestic flexibility in setting ... [non-tariff measures, as well as] to bolster regulatory capacity in developing countries' (World Trade Organization 2012, 217).

On a more theoretical basis, the Havana Charter is an outstanding case to demonstrate how the object of trade policy can be defined as the latent, possible or effective contestability underpinning domestic legitimacy and international recognition of state practices considered for their impact on the trading system. Instead of viewing the trading system as an outcome of trade-offs between demands for free-trade and protectionist policies, such an approach leads to considering that these various practices can shape at great variance the spatial structures of the trading system. They can, for instance, provide room for heterogeneity and weaker actors, in contrast to the powerful homogenous propensity of market fundamentalism. Different formulae may accordingly apply to the variety of products affected. We have seen, for instance, that raw materials were treated completely differently from manufactured goods or farm products.

$<\mathrm{a}>$ CONCLUSIONS

In a context of increasing doubts regarding the far-reaching consequences of the current global crisis of neoliberal globalization, the key question addressed by the negotiators of the Havana Charter remains as genuine as ever: how could a compatible relation between the transnationalization of capitalism and the economic and social role of the political authority be defined on a comprehensive scope? Seventy years after the signing of the Havana Charter, this agreement still offers some lessons for constructing credible alternatives to conventional thinking on economic development. Conventional wisdom takes it that, as globalization proceeds, the range of government practices considered to have an impact on trade has broadened; the implication being that economic policies should converge on a global market rule. This study makes it clear that the comprehensive scope of the challenge of deep integration is in fact not so new. Seventy years ago, the issues addressed by the Havana Charter already focused on non-tariff measures, such as quantitative restrictions, full employment provisions, agricultural support, subsidies, investment rights and other regulatory issues. Yet, broadening the scope of trade policy issues did not mean applying market mechanisms to more and more aspects of social life. The provisions of the Havana Charter attempted to make trade the servant rather than the master of states whose economic and social functions became critical to their legitimacy.

\section{$<\mathrm{a}>$ REFERENCES}

Banerjee, A.V. and E. Duflo. 2011. Poor Economics: A Radical Rethinking of the Way to Fight Global Poverty. New York: PublicAffairs. Gardner, R.N. 1969. Sterling Dollar Diplomacy: The Origins and Prospect of Our International Economic Order. Oxford: Oxford University Press.

Graz, J.-C. 1999. Aux sources de l'OMC: La Charte de La Havane, 1941-1950. Precursor of the WTO: The Stillborn Havana Charter, 1941-1950: Precursor to the WTO: The Stillborn Havana Charter, 1941-1950. Genève: Librairie Droz.

Graz, J.-C. 2004. 'Transnational Mercantilism and the Emergent Global Trading Order', Review of International Political Economy 11, 590-610.

Helleiner, E. 2014. Forgotten Foundations of Bretton Woods: International Development and the Making of the Postwar Order. Ithaca, NY: Cornell University Press. 
Hont, I. 2005. Jealousy of Trade: International Competition and the Nation-State in Historical Perspective. Cambridge, MA: Harvard University Press.

Perrotta, C. 1991. 'Is the Mercantilist Theory of the Favorable Balance of Trade Really Erroneous?', History of Political Economy 23, 310336.

Reinert, E.S. 2008. How Rich Countries Got Rich ... and Why Poor Countries Stay Poor. New York: PublicAffairs.

Toye, R. 2003. 'Developing Multilateralism: The Havana Charter and the Fight for the International Trade Organization, 1947-1948', International History Review 25, 282-305.

Toye, J. and R. Toye. 2004. The UN and Global Political Economy: Trade, Finance, and Development. Bloomington, IN: Indiana University Press.

Wilcox, C. 1949. A Charter for World Trade. New York: Macmillan.

World Trade Organization. 2012. World Trade Report 2012: Trade and Public Policies: A Closer Look at Non-Tariff Measures in the 21st Century. Geneva: WTO.

Zeiler, T.W. 1999. Free Trade, Free World: The Advent of GATT. Chapel Hill, NC, USA and London, UK: University of North Carolina Press. 